\title{
PERAN SERTA MASYARAKAT DALAM PENCEGAHAN TINDAK \\ PIDANA KORUPSI PENGELOLAAN KEUANGAN DANA DESA, STUDI DI DESA CAU BELAYU, KECAMATAN MARGA, KABUPATEN TABANAN, PROPINSI BALI
}

\author{
I Made Walesa Putra \\ I Gusti Agung Ayu Dike Widhiyaastuti \\ I Putu Rasmadi Arsha Putra \\ Universitas Udayana \\ Email: mdwalesaputra@yahoo.com
}

\begin{abstract}
ABSTRAK
Korupsi sebagai tindak pidana merugikan keuangan negara, masyarakat dan orang-perorangan, tergolong white collar crime merupakan musuh utama Bangsa Indonesia selain kejahatan narkotika, dan terorisme. Pemberantasan korupsi tidak hanya melalui penegakan hukum (represif) namun langkah pencegahan harus lebih diutamakan. Dana Desa bertujuan memajukan kesejahteraan masyarakat desa melalui program-programnya, sehingga perlu dilakukan pencegahan penyelewengan dalam pemanfaatannya termasuk juga di Desa Cau Belayu, Kecamatan Marga, Kabupaten Tabanan, Propinsi Bali.

Metode pendekatan secara Yuridis Empiris, yaitu penelitian hukum dengan cara pendekatan fakta yang ada dengan jalan mengadakan pengamatan dan penelitian melalui wawancara mendalam terhadap objek penelitian.

Hasil penelitian pemahaman warga Desa Cau Blayu masih sangat minim tentang tindak pidana korupsi, serta pentingnya peran warga dalam mencegah terjadi tindak pidana korupsi khususnya sehubungan pengelolaan dana desa. Ada beberapa kendala dan hambatan yang ditemui pada kenyataannya di lapangan oleh Masyarakat serta Perangkat Desa Cau Blayu sehubungan pengelolaan dana desa serta pada khususnya sebagai upaya pencegahan korupsi penggunaan dana desa, namun dengan pengelolaan dana desa yang baik, transparan, dan akuntable sesuai dengan ketentuan perundangundang didukung peran serta masyarakat mengawasi dan melaporkan penyelewengannya, sebagai salah satu upaya pencegahan korupsi untuk meningkatkan efektifitas pembangunan dan kesejahteraan masyarakat desa di sekitarnya.
\end{abstract}

Kata Kunci: Peran Masyarakat, Pencegahan, Korupsi, Dana Desa

\section{ABSTRACT}

Corruption is as a criminal act which harm the financial of the state, society and individuals.It classified as white collar crime which main enemy of the Indonesian Nation to narcotics crime and terrorism. Combating corruption is not only through law enforcement (repressive) but precautionary measures should take precedence. Village Fund aims to promote the welfare of rural communities through its programs, so it is necessary to prevent abuse in its utilization, including in CauBelayu Village, MargaSubdistrict, Tabanan Regency, Bali Province.

This study use Juridical Empirical approach method, namely legal research by way of existing facts approach and by conducting observations and research through depth interviews of the object of research.

The results of the understanding of CauBlayu villagers are still very minimum about corruption, as well as the importance of citizens' role in preventing corruption, especially in relation to the management of village funds. There are several obstacles encountered in reality by CauBlayu Village Community and Official in relation to the management of village funds and in particular as an effort to prevent corruption in the use of village funds, but with good, transparent and accountable village fund management based on the law, supported by the role of the community in monitoring and reporting its abuse, as one of the efforts to prevent corruption to improve the effectiveness of the development and welfare of surrounding villagers.

Keywords: Community Role, Prevention, Corruption, Village Fund 


\section{PENDAHULUAN}

\subsection{Latar Belakang}

Korupsi adalah perbuatan curang, tindak pidana yang merugikan keuangan negara, demikian menurut Subekti dan Tjitrosoedibio dalam Kamus Hukum Tahun 1969. ${ }^{1}$ Pengertian secara yuridis, baik dalam arti maupun jenisnya telah dirumuskan di dalam UU No 31 Tahun 1999 jo UU No 20 Tahun 2001 tentang Pemberantasan Tindak Pidana Korupsi dan undang-undang sebelumnya, yaitu UU No 3 Tahun 1971. Dalam pengertian yuridis, pengertian korupsi tidak hanya terbatas pada perbuatan yang memenuhi rumusan delik dapat merugikan keuangan negara, tetapi meliputi juga perbuatanperbuatan yang memenuhi rumusan delik, yang merugikan masyarakat atau orangperseorangan.

Perbuatan

tersebut merupakan suatu penyakit yang kerap terjadi terutama pada negara berkembang seperti Indonesia, dimana perkembangan korupsi di Indonesia dinilai oleh beberapa pakar sudah sangat memprihatinkan. Bahkan secara agak berlebihan M.Abdul Kholik, AF. mengatakan, bagi bangsa Indonesia, seperti telah ditakdirkan sebagai problema yang seakan tidak pernah habis untuk dibahas ${ }^{2}$. Dikatakan berlebihan karena pada hakikatnya korupsi bukan sebuah takdir tapi sebagai penyakit, dan sebagai penyakit tentulah ada obatnya sekalipun memerlukan

${ }^{1}$ Evi Hartanti, 2012, Tindak Pidana Korupsi Edisi Kedua,Sinar Grafika, Jakarta, hlm.9.

${ }^{2} \mathrm{M}$ Abdul Kholik, AF., Eksistensi KPK dalam Peradilan Korupsi di Indonesia, Artikel dalam Jurnal Hukum FH UII, No.26, Vol.11, hlm 29. suatu proses yang panjang. Sebagai suatu penyakit korupsi pada hakikatnya tidak saja membahayakan keuangan negara, Frans Magnis Suseno menjelaskan bahwa praktik korupsi di Indonesia telah sampai pada yang paling membahayakan dalam kehidupan berbangsa dan bernegara. ${ }^{3}$

Pelaku tidak seperti halnya penjahat konvensional yang melakukan aksinya secara biasa yaitu dengan kekerasan, tetapi aksinya dilakukan sangat rapi, tersembunyi, sistematis dan terorganisir, korupsi umumnya justru lebih merugikan daripada kejahatan konvensional, lebih berdampak luas terhadap korban yang banyak karena dilakukan oleh orang-orang pintar, mempunyai kedudukan dan peranan penting dalam tatanan sosial masyarakat, yang justru menyalahgunakan kelebihan mereka itu. Sehingga korupsi tergolong kejahatan kerah putih atau white collar crime, dimana sebagai salah satu musuh utama Bangsa Indonesia selain kejahatan narkotika, dan terorisme.

Indonesia telah memiliki peraturan lengkap bahkan dengan ancaman sanksi sangat berat dalam undang-undang antara lain dalam: Kitab Undang-Undang Hukum Pidana (KUHP), UU No 31 Th 1999 tentang Pemberantasan Tindak Pidana Korupsi, sebagaimana telah diubah dengan Undang-Undang Nomor 20 Tahun 2001 tentang Perubahan atas UU No 31 Th 1999 tentang Pemberantasan Tindak Pidana Korupsi dan UU No 30 Th 2002 tentang Komisi

\begin{tabular}{llrr}
\cline { 3 - 3 } & ${ }^{3}$ R.Dyatmiko & Soemodihardjo, & 2008, \\
Mencegah & $n$ & Memberantas & Korupsi, \\
Mencermati & Dinamikanya di & Indonesia, \\
Prestasi Pustaka, Jakarta, hlm 3. &
\end{tabular}
Prestasi Pustaka, Jakarta, hlm 3. 
Pemberantasan Tindak Pidana Korupsi, meskipun demikian koruptor masih belum kapok melakukan aksinya, selalu ada koruptor-koruptor baru sehingga diperlukan upaya yang efektif dalam penanggulangannya. Upaya represif melalui penegakkan hukum pidana hanya dapat dilakukan oleh aparat penegak hukum yaitu seperti Kepolisian dan Komisi Pemberantasan Korupsi (KPK), namun jauh lebih baik jika diefektifkan upaya pencegahan yang tidak hanya dapat dilakukan aparat penegak hukum, yang juga merupakan kewajiban dan dapat dilakukan oleh seluruh warga Negara Indonesia. Pencegahan selalu lebih baik daripada mengobati, untuk menghindari kerugian lebih besar efek dari tindak pidana korupsi.

Pembentuk undang-undang dalam usaha memberantas korupsi telah memasukkan ketentuan tentang peran serta masyarakat dalam usaha pencegahan korupsi di Indonesia, peran serta ini dilatarbelakangi:

1. Dengan diberikannya hak dan kewajiban masyarakat dalam usaha penanggulangan korupsi dipandang sebagai hal positif dalam upaya pencegahan dan pengungkapan kasus-kasus korupsi yang terjadi.

2. Persoalan penanggulangan korupsi dipandang bukan semata-mata menjadi urusan pemerintah atau penegak hukum, melainkan merupakan persoalan semua rakyat dan urusan bangsa.

Sementara itu, mengenai Dana Desa, sebagaimana diatur dalam Peraturan Pemerintah No 60 Tahun 2014 tentang Dana Desa yang Bersumber dari Anggaran Pendapatan Belanja Negara (APBN) dan dengan perubahannya yang terakhir berdasarkan Peraturan Pemerintah No 8 Tahun 2016 tentang Perubahan Kedua atas Peraturan Pemerintah No 60 Tahun 2014 tentang Dana Desa yang Bersumber dari Anggaran Pendapatan dan Belanja Negara, Pasal 1 Ayat (2) menyebutkan; Dana Desa adalah dana yang bersumber dari APBN yang diperuntukkan bagi desa yang ditransfer melalui Anggaran Pendapatan dan Belanja Daerah (APBD) Kabupaten/Kota dan digunakan untuk membiayai penyelenggaraan pemerintah, pelaksanaan pembangunan, pembinaan kemasyarakatan, dan pemberdayaan masyarakat. Selanjutnya Pasal 6 disebutkan bahwa Dana Desa tersebut ditransfer melalui APBD Kabupaten/Kota untuk selanjutnya ditransfer ke Anggaran Pendapatan dan Belanja Desa (APB) Desa. ${ }^{4}$

Demikian halnya di Desa Cau Belayu, desa yang memiliki visi yaitu terwujudnya Masyarakat Mandiri dan Sejahtera. Mandiri berarti mampu untuk mengorganisir diri untuk memobilisasi sumber daya yang ada, mampu mengatasi permasalahan yang timbul. Sejahtera berarti dapat melayani masyarakat secara maksimal untuk memenuhi kebutuhan. ${ }^{5}$

Sedangkan misi Desa Cau Belayu yaitu memberdayakan masyarakat desa dalam rangka menanggulangi suatu masalah antara lain:

- Peningkatan Kapasitas Masyarakat dan Kelembagaannya

- Pelembagaan Sistem Pembangunan Partisipatif

- Pengoptimalan Fungsi dan Peran Pemerintah Desa

${ }^{4} \mathrm{Ni}$ Putu Leona Laksmi Suryadi, 2016, Penanggulangan Tindak Pidana Korupsi dalam Pengelolaan Keuangan Dana Desa di Bali, Skripsi, Fakultas Hukum, Unud, hlm 50. ${ }^{5}$ ibid 
- Peningkatan Kwalitas dan Kwantitas Pembangunan

- Pengembangan Kemitraan dalam pembangunan

Sebagaimana desa lainnya, Desa Cau Belayu tentunya juga memperoleh Dana Desa seperti diatur dalam Peraturan Pemerintah No 60 Tahun 2014, serta melihat visi dan misi yang dimiliki Desa Cau Belayu, adalah sangat relevan apabila dijadikan tempat penelitian terkait bagaimana peran masyarakat desa dalam pencegahan korupsi dalam pengelolaan keuangan dana desa. Diharapkan memberikan edukasi serta membangun kesadaran masyarakat akan pentingnya menjalankan pemerintahan di desa yang bersih, transparan dan akuntable serta melakukan pencegahan korupsi sedini mungkin dan se-efektif mungkin.

Peran serta masyarakat dalam upaya pencegahan dan pemberantasan tindak pidana korupsi diwujudkan dalam bentuk antara lain mencari, memperoleh, memberikan data atau informasi tentang tindak pidana korupsi dan hak menyampaikan saran dan pendapat secara bertanggung jawab terhadap pencegahan dan pemberantasan tindak pidana korupsi. Sesuai dengan prinsip keterbukaan dalam negara demokrasi yang memberikan hak kepada masyarakat untuk memperoleh informasi yang benar, jujur, dan tidak diskriminatif mengenai

pencegahan dan pemberantasan tindak pidana korupsi.

Sesungguhnya membudayakan upaya peranan masyarakat dalam pemberantasan korupsi, secara teoritis merupakan kewajiban. Ditunjukkan pada Pasal 108 (1) KUHP :
"Setiap

orang

yang

mengalami, melihat, menyaksikan dan atau menjadi korban peristiwa yang merupakan tindak pidana berhak untuk mengajukan laporan atau pengaduan kepada penyelidik dan atau penyidik baik lisan maupun tertulis."

Lembaga Transparency International (TI) merilis data indeks persepsi korupsi (Corruption Perception Index/CPI) untuk tahun 2015, Indonesia menempati peringkat ke 88 dengan skor CPI 36. Skor tersebut meningkat dari tahun 2014 yang berada di peringkat ke 107. Peningkatan CPI Indonesia ini dipengaruhi oleh akuntabilitas publik yang meningkat dan juga pencegahan korupsi yang dinilai efektif, KPK sangat berperan. Peringkat negara-negara tersebut merupakan gambaran terhadap daya tahan dan upaya pemerintah masing-masing beserta masyarakatnya dalam menekan korupsi. Skor rata-rata tahun 2015 adalah 43. Artinya skor Indonesia masih di bawah ratarata skor persepsi dunia. Di Asia Tenggara, Indonesia ada di bawah Singapura, Malaysia, dan Thailand. ${ }^{6}$

Melihat peringkat Indonesia di indeks korupsi yang telah membaik, tetapi masih buruk, sehingga diharapkan kedepan penelitian-penelitian serta edukasi kepada masyarakat dapat lebih membantu meningkatkan rangking Indonesia terhadap isu anti korupsi, melalui pencegahan korupsi dari tingkat desa, dimulai di Bali khususnya di Desa Cau Belayu, diharapkan

$\stackrel{2}{ }$\begin{tabular}{l} 
Bagus \\
\cline { 2 - 3 } https://m.tempo.co/read/news/2016/01/27/0637
\end{tabular}
39957/ini-daftar-peringkat-korupsi-dunia-
indonesia-urutan-berapa, diakses 10 Maret
2016.
2016. 
dapat dilanjutkan di desa-desa lainnya diseluruh tanah air, sebagai upaya penanggulangan korupsi guna meningkatkan pembangunan desa dan kesejahteraan seluruh warga desa dalam Negara Kesatuan Republik Indonesia.

\subsection{Tujuan Penelitian}

Terdapat tujuan penulisan karya ilmiah ini dengan berpedoman pada penelitian yang telah dilakukan sebelumnya adalah sebagai berikut:

1. Mengetahui pemahaman warga di

Desa Cau Belayu mengenai arti pentingnya mencegah tindak pidana korupsi dalam pengelolaan keuangan dana desa serta peran serta masyarakat dalam Pencegahan Tindak Pidana Korupsi pengelolaan keuangan dana desa?

2. Bagaimana upaya penanggulangan hambatan-hambatan agar pengelolaan keuangan dana desa di Indonesia khususnya desa di Bali terhindar dari Korupsi?

\section{METODE PENELITIAN}

Untuk memperoleh suatu pembahasan sesuai dengan apa yang terdapat di dalam tujuan penyusunan bahan analisis, maka dalam penulisan penelitian ini menggunakan metode pendekatan secara Yuridis Empiris, yaitu penelitian hukum dengan cara pendekatan fakta yang ada dengan jalan mengadakan pengamatan dan penelitian dilapangan kemudian dikaji dan ditelaah berdasarkan peraturan perundang-undangan yang terkait sebagai acuan untuk memecahkan masalah, dalam hal ini pendekatan tersebut digunakan untuk menganalisis secara kualitatif ${ }^{7}$.

\footnotetext{
${ }^{7}$ Rony Hanitijo Soemitro, 1998, Metode Penelitian Hukum dan Jurimetri, Ghalia Indonesia, Jakarta, hlm. 52.
}

Pendekatan yuridis empiris yaitu suatu pendekatan yang dilakukan untuk menganalisis tentang sejauh mana suatu peraturan atau perundangundangan atau hukum berlaku secara efektif dalam masyarakat, ${ }^{8}$ yaitu terkait Pencegahan Tindak Pidana Korupsi Dana Desa di Desa Cau Belayu, Kecamatan Marga, Kabupaten Tabanan, Propinsi Bali.

III. HASIL PEMBAHASAN

DAN

3.1. Peran Serta Masyarakat Desa Dalam Pencegahan Tindak Pidana Korupsi Pengelolaan Keuangan Dana Desa di Desa Cau Belayu, Kecamatan Marga, Kabupaten Propinsi Bali

Korupsi Tabanan, merupakan penggunaan jabatan untuk tujuan di luar kepentingan resmi. Korupsi sendiri terdiri atas berbagai jenis: suap, pemerasan, menjajakan pengaruh, nepostisme, pemalsuan, uang pelicin, penggelapan dan sebagainya. Kita cenderung melihat korupsi sebagai sematamata dosa pemerintah, tetapi sebenarnya pihak swasta juga banyak terlibat dalam korupsi yang terjadi di sektor pemerintah. Kita semua terlibat, karena itu kita harus bergandengan tangan dan bersama-sama mencari jalan keluar. ${ }^{9}$

Beberapa pendapat pakar hukum serta perumusan definisi korupsi dalam peraturan

${ }^{8}$ Kuntjaraningrat, 1999, Kebudayaan, Metalitet \& Pembangunan, Gramedia, Jakarta,hlm

${ }^{9}$ Robert Klitgaard, dkk., 2002, Penuntun Pemberantasan Korupsi dalam Pemerintahan Daerah, Yayasan Obor Indonesia \& Partnership for Governance Reform in Indonesia, Jakarta, hlm. 109. 
perundangan, ada beberapa unsur-unsur mutlak atau pokok korupsi, berupa: a. adanya pelaku atau pelaku-pelaku korupsi; b. adanya tindakan yang melanggar norma-norma yang berlaku yang dalam ini dapat membentuk moral (aspek agama), etika (aspek profesi), maupun peraturan perundang-undangan (aspek hukum); c. adanya unsur merugikan keuangan /kekayaan negara atau masyarakat, langsung atau tidak langsung, serta; d. adanya unsur atau tujuan untuk kepentingan atau keuntungan pribadi/keluarga /golongan. ${ }^{10}$

Sedangkan perspektif pidana, secara spesifik unsur-unsur kecenderungan perbuatan merugikan keuangan negara dapat dianalisis dari 4 pendekatan yaitu: ${ }^{11}$

1) Adanya pelaku perbuatan merugikan keuangan negara, umumnya berkaitan dengan pejabat negara atau penyelenggara negara;

2) Perbuatan melawan hukum, penyalahgunaan jabatan, kewenangan dan kekuasaan pengelolaan keuangan negara.

3) Terjadi kerugian negara secara nyata dan pasti, dapat dinilai dengan jumlah uang.

4) Adanya pihak yang "memperoleh keuntungan secara tidak wajar atau memperkaya"; diri sendiri, orang lain atau korporasi, yaitu dengan mengurangi hak penerimaan keuangan negara atau menimbulkan kewajiban membayar oleh negara "yang

${ }^{10}$ IGM Nurdjana, 2010, Sistem Hukum Pidana dan Bahaya Laten Korupsi, Perpektif Tegaknya Keadilan Melawan Mafia Hukum, Pustaka Pelajar, Yogyakarta, hlm 20.

${ }^{11}$ Hernold Ferry Makawimbang, 2015, Memahami dan Menghindari Perbuatan Merugikan Keuangan Negara, dalam TIndak Pidana Korupsi dan Pencucian Uang, Thafa Media, Yogyakarta, hlm 98-99. seharusnya tidak ada" atau "membayar lebih besar dari yang seharusnya", secara melawan hukum.

Upaya

pemberantasan korupsi sudah sejak dahulu dilakukan baik upaya represif maupun preventif, namun sampai dengan saat ini masih banyak koruptor yang melakukan aksinya sekalipun ancaman sanksinya sudah sangat berat dan mendapatkan reaksi pencelaan yang keras dari masyarakat.

Pemerintah salah satunya menempuh cara pemberantasan serta pencegahan dengan mengeluarkan perundang-undangan yang mengatur tindak pidana korupsi sampai dengan saat ini termasuk diantaranya:

1) Peraturan Penguasa Militer Nomor. Prt/Perpu/1957 tentang Pemberantasan Korupsi;

2) UU No 24/Prp/1960 dan Keputusan Presiden No 228 Tahun 1967 tentang Tindak Pidana Korupsi;

3) UU No 3 Tahun 1971 tentang Pemberantasan Tindak Pidana Korupsi;

4) UU No 28 Tahun 1999 Tentang Penyelenggaraan Negara Yang Bersih, Berwibawa, Bebas Korupsi dan Kolosi dan Nepotisme;

5) UU No 31 Tahun 1999 Tentang Pemberantasan Tindak Pidana Korupsi yang telah diubah dengan UndangUndang Nomor 20 Tahun 2001 Tentang Pemberantasan Tindak Pidana Korupsi;

6) UU No 15 Tahun 2002 Tentang Pemberantasan Tindak Pidana Pencucian Uang, yang telah diubah dengan Undang-Undang Nomor 8 Tahun 2010 tentang Tindak Pidana Pencucian uang; 
7) UU No 30 Tahun 2002 Komisi Pemberantasan Tindak Pidana Korupsi;

8) UU No 46 Tahun 2009 tentang Peradilan Tindak Pidana Korupsi.

Lebih jauh bukan hanya tingkat nasional, masyarakat internasional pun telah memusatkan perhatian terhadap masalah korupsi melalui United Nation Convention Against Corruption (UNCAC) pada tanggal 11 Desember Tahun 2003 di Merida, Mexico yang diratifikasi dengan UndangUndang Nomor 7 Tahun 2006, menegaskan bahwa Indonesia merupakan bagian masyarakat global memerangi korupsi.

Dengan disahkannya UndangUndang No 6 Tahun 2014 tentang Desa pada tanggal 15 Januari 2014, mengakibatkan perubahan signifikan dalam pengelolaan desa. Pentingnya pengelolaan dana desa yang baik, menjadi fokus perhatian mengingat yaitu besarnya dana yang mengalir ke desa, regulasi yang relatif baru, dan luasnya serta variatifnya karakteristik desa, yang juga rawan ditunggangi kepentingan politik tertentu, serta potensi korupsi dapat meningkat di daerah.

Besarnya jumlah dana desa sebagaimana disampaikan Menteri Desa Pembangunan Daerah Tertinggal dan Transmigrasi (Mendes PDTT), dana desa ditahun 2017 Rp. 60 triliun bahkan akan meningkat menjadi Rp. 120 triliun di tahun 2018. Tahun 2017, rata-rata desa mendapatkan uang Rp. 800 juta ditambah dari kabupaten dan provinsi sehingga masing-masing memperoleh Rp.1,6 miliar ${ }^{12}$

${ }^{12}$ https://news.detik.com/news/berita/d3487085/mendes - tahun - depan - alokasi dana - naik - tiap -desa/jumat 28 April 2017, diakses tanggal 15 Oktober 2017.
Penggunaan dana desa sebagaimana diatur terakhir berdasarkan Permendes No.4 Tahun 2017 tentang Perubahan atas Permendesa No 22 Tahun 2016 tentang Penetapan Prioritas Penggunaan Dana Desa, sebagai berikut:

1) Prioritas penggunaan dana desa untuk membiayai pelaksanaan program dan kegiatan di bidang pembangunan desa dan pemberdayaan masyarakat desa.

2) Prioritas penggunaan dana desa diutamakan untuk membiayai pelaksanan program dan kegiatan yang bersifat lintas bidang.

3) Program dan kegiatan sebagaimana dimaksud pada ayat (2) terutama bidang kegiatan BUMDesa atau BUMDesa Bersama, embung, produk unggulan desa atau kawasan perdesaan dan sarana olahraga desa.

4) Prioritas penggunaan dana desa sebagaimana dimaksud pada ayat 1, dipublikasikan kepada masyarakat oleh Pemerintah Desa di ruang publik atau ruang yang dapat diakses masyarakat Desa.

Dengan mengetahui dan memahami pengaturan tentang prioritas penggunaan dana desa, dapat sebagai upaya untuk mendeteksi adanya penyelewengan terhadap penggunaan Dana Desa. Peraturan Menteri Desa memprioritaskan, yaitu pembangunan desa dan pemberdayaan masyarakat desa. Prioritas kegiatan, anggaran dan belanja desa disepakati dalam Musyawarah Desa yang partisipatif. Dimana hasil musyawarah sebagai acuan Rencana Kerja Pemerintah Desa (RKPDesa) dan APBDesa. 
Namun Permen ini, ditegaskan desa tetap miliki ruang berkreasi program/kegiatan sesuai kewenangan, analisa kebutuhan prioritas dan sumber daya.

Pengelolaan dana desa kerap menjadi persoalan karena tidak mengacu pedoman/peraturan, tidak sesuai dokumen perencanaan desa yaitu RPJM Desa dan Rencana Kerja Pembangunan Desa, serta tidak jarang penyusunan dan pelaksanaan program tanpa musyawarah desa. Akibatnya tidak sesuai rencana anggaran biaya.

Pengawasan dana desa sangat diperlukan untuk mencegah penyelewenangan atau korupsi dana tersebut, selama ini Pengawasan dana desa oleh masyarakat melalui BPD (Badan Permusyawaratan Desa) dan pemerintah di atasnya berdasakan undang-undang. Aparat pengawas internal pemerintah yakni Badan Pengawasan Keuangan dan Pembangunan (BPKP), Inspektorat Jenderal (KemenDes, KemenDagri, dan KemenKeu), serta Badan Pengawas Daerah Provinsi/Kabupaten/Kota. Juga aparat pemerintah yaitu aparat pemerintah Desa, Provinsi/ Kabupaten/ Kota khususnya Badan Pemberdayaan Masyarakat Desa

(BPMD)

Kabupaten/Provinsi. Serta tentunya Kemendes telah menggandeng Komisi Pemberatasan Korupsi untuk pengawasan dana desa. ${ }^{13}$

Peran serta masyarakat menjadi salah cara satu penting dalam pencegahan penyelewenangan penyaluran dana desa, sebagaimana studi yang dilakukan di Desa Cau

\footnotetext{
${ }^{13}$ https://nasional.tempo.co/read/899049/in i - upaya-kpk -cegah-terjadinya -korupsi- danadesa/diakses tanggal 15 Oktober 2017.
}

Belayu, Kecamatan Marga, Kabupaten Tabanan, Propinsi Bali. Masyarakat Desa Cau Belayu sampai dengan tahun 2017 telah memperoleh manfaat Program Pemerintah mengenai Dana Desa.

Beberapa

implementasi dana desa sehubungan penggunaan dana desa untuk membiayai pelaksanaan program dan kegiatan di bidang pembangunan desa tersebut antara lain: pembangunan infrastruktur jalan lingkungan dusun, pembetonan jalan subak dan terlaksananya PAM desa. Sementara itu pemberdayaan masyarakat desa di Desa Cau Blayu melalui pengembangan ekonomi rakyat, misalnya pelatihan usaha untuk membuat abon babi, serta sarana kesehatan.

Namun sedikit disayangkan, berdasarkan diskusi dan wawancara terhadap perangkat dan warga Desa Cau Blayu pemahaman masih sangat minim tentang tindak pidana korupsi, serta pentingnya peran warga dalam mencegah terjadinya tindak pidana korupsi khususnya sehubungan dengan pengelolaan dana desa. Selama ini masyarkat hanya menyaksikan dari surat kabar atau berita dari media televisi terkait korupsi yang terjadi secara nasional di Indonesia, sementara itu lebih detail terkait pengaturan tentang korupsi serta spesifik tentang kewenangan dan tanggungjawab masyarakat membantu upaya preventif atau pencegahan korupsi belum diketahui dengan baik.

UU No 31 Tahun 1999 tentang Pemberantasan Tindak Pidana Korupsi sebagaimana telah diubah dengan UU Nomor 20 Tahun 2001 tentang Pemberantasan Tindak Pidana 
Korupsi Pasal 41 mengatur tentang peran serta masyarakat dalam pencegahan dan pemberantasan tindak pidana korupsi, yang bentuknya antara lain:

a. Hak mencari, memperoleh dan memberikan informasi adanya dugaan telah terjadi tindak pidana korupsi;

b. Hak untuk memperoleh pelayanan dalam mencari, memperoleh dan memberikan informasi dari penegak hukum yang menangani perkara korupsi;

c. Hak menyampaikan saran dan pendapat secara bertanggungjawab kepada penegak hukum yang menangani perkara tindak pidana korupsi;

d. Hak untuk memperoleh jawaban atas pertanyaan tentang laporannya yang diberikan kepada penegak hukum dalam waktu paling lama 30 hari;

e. Hak untuk mendapatkan perlindungan hukum dalam hal:
1) Melaksanakan haknya sebagaimana dimaksud dalam huruf a, b, c;

2) Diminta hadir dalam proses penyelidikan, penyidikan, dan di sidang pengadilan sebagai saksi pelapor, saksi, atau saksi ahli, sesuai dengan ketentuan peraturan perundang-undangan yang berlaku.

Selanjutnya Pasal 42 ayat 1 dijelaskan bahwa pemerintah memberikan penghargaan kepada anggota masyarakat yang telah berjasa membantu upaya pencegahan, pemberantasan, atau pengungkapan tindak pidana korupsi.

Pengaturan tentang peran serta masyarakat juga diatur dalam Undang-Undang Nomor 28
Tahun

1999

tentang

Penyelenggaraan Negara yang Bersih dan Bebas dari KKN, khususnya dalam Pasal 8 ayat 1 dimana disebutkan bahwa peran serta masyarakat dalam penyelenggaraan negara merupakan hak dan tanggung jawab masyarakat untuk ikut mewujudkan Penyelenggara Negara yang bersih. ${ }^{14}$

Kemudian dalam Penjelasan Pasal 8 ayat 1 disebutkan Peran serta masyarakat sebagaimana dimaksud dalam ayat ini, adalah peran aktif masyarakat untuk ikut serta mewujudkan Penyelenggara Negara yang bersih dan bebas dari korupsi, kolusi, dan nepotisme, yang dilaksanakan dengan menaati norma hukum, moral, dan sosial yang berlaku dalam masyarakat. Sedangkan Pasal 9 lebih lanjut menjelaskan:wujud dari peran serta masyarakat antara lain;

a. Hak mencari memperoleh dan memberikan informasi tentang penyelenggaraan Negara;

b. Hak untuk memperoleh pelayanan yang sama dan adil dari Penyelenggara Negara;

c. Hak menyampaikan saran dan pendapat secara bertanggung jawab terhadap kebijakan Penyelenggara Negara;

d. Hak memperoleh perlindungan hukum.

Undang Undang Nomor 30 tahun 2002 tentang Komisi Pemberantasan Korupsi Pasal 1 ayat 3 juga mengatur soal peran serta masyarakat dimana disebutkan bahwa Pemberantasan korupsi adalah serangkaian tindakan untuk mencegah dan

\footnotetext{
${ }^{14}$ Ganjar Laksamana, 2015, Laporan Tim Pengkajian Hukum tentang Partisipasi Aktif Publik dalam Pencegahan dan Pemberatasan Korupsi, Pusat Penelitian dan Pengembangan Sistem Hukum Nasional, Badan Pembinaan Hukum Nasional, Kemeterian Hukum dan Hak Asasi Manusia, h. 22.
} 
memberantas tindak pidana korupsi melalui upaya koordinasi, supervisi, monitor, penyelidikan, penyidikan, penuntutan dan pemeriksaan di sidang pengadilan dengan peran serta masyarakat berdasarkan peraturan undang-undang yang berlaku.

Bahkan berdasarkan

Peraturan Pemerintah No 71 Tahun 2000 telah mengatur lebih lanjut tentang Tata Cara Pelaksanaan Peran Serta Masyarakat dan Pemberian Penghargaan dalam Pencegahan dan Pemberantasan Tindak Pidana Korupsi. Sehingga tidak hanya sebatas cara masyarakat berperan mencegah korupsi bahkan pemberian reward atau penghargaan kepada mereka yang membantu dalam pencegahan korupsi.

Dengan demikian, adanya kelengkapan pengaturan mengenai peran serta masyarakat melakukan pencegahan korupsi tersebut dijelaskan mulai dari KUHP, sampai dengan pengaturan khusus korupsi dan dana desa dan peraturan pelaksanaannya, maka peran serta masyarakat dalam mencegah korupsi penggunaan dana desa khususnya, dapat di optimalkan melalui sosialisasi yang efektif ataupun pelatihan yang berkelanjutan yang selama ini masih belum maksimal dilakukan pemerintah.

\subsection{Upaya Penanggulangan Hambatan-Hambatan Agar Pengelolaan Keuangan Dana Desa Di Indonesia Khususnya Desa Di Bali Terhindar Dari Korupsi}

Permasalahan korupsi merupakan permasalahan yang sangat sulit untuk diberantas oleh karena sangat kompleks yang menurut Barda Nawawi Arif bahwa hal tersebut disebabkan karena korupsi berkaitan erat dengan kompleksitas masalah lain seperti: masalah sikap mental/moral, masalah pola/sikap hidup dan budaya sosial, masalah kebutuhan/tuntutan ekonomi dan struktur/sistem ekonomi, masalah lingkungan hidup/sosial dan kesenjangan sosial-ekonomi, masalah struktur/budaya politik, masalah peluang yang ada di dalam mekanisme pembangunan atau kelemahan birokrasi/prosedur administrasi (termasuk sistem pengawasan) di bidang keuangan dan pelayanan umum. ${ }^{15}$

Disamping kesulitan tersebut, dirasakan belum maksimal efek jera para pejabat atau penyelenggaran negara melihat ancaman pidana yang berat dan telah banyak koruptor tertangkap namun seakan tidak kapok atau seperti penyakit menular yang tidak ada habisnya, korupsi masih saja terjadi. Beberapa diantaranya terkait dengan penggunaan dana desa.

Operasi tangkap tangan KPK awal Agustus 2017 terhadap Bupati Pamekasan, Kepala Kejaksaan Negeri Pamekasan (Kajari), Kepala Desa Dassok dan 2 orang aparatur sipil. Langkah yang dilakukan KPK itu terkait dugaan suap kepada aparat penegak hukum untuk menghentikan penanganan kasus korupsi penyelewengan dana desa. ${ }^{16}$ Periode Agustus 2016Agustus $2017 \quad$ Indonesia Coruption Watch (ICW)

\footnotetext{
${ }^{15}$ IGM Nurdjana, op.cit, 29.

${ }^{16} \mathrm{http}: / /$ www.hukumonline.com/berita/bac a/lt598f2a9e656ee/cegah-korupsi--masyarakatperlu-dilibatkan-awasi-dana-desa, Sabtu, 12 Agustus 2017, diakses tanggal 10 Oktober 2017.
} 
menghitung ada 110 kasus korupsi anggaran desa yang diproses penegak hukum dan melibatkan 139 pelaku (dimana 107 orang diantaranya merupakan kepala desa) dengan kerugian negara sedikitnya Rp30 miliar.

Komisi Pemberantasan Korupsi mencatat, selama Januari-Juni 2017, ada 459 laporan terkait dengan dana desa. Laporan itu disampaikan ke KPK melalui telepon, SMS, surat elektronik, atau datang langsung. ${ }^{17}$ Isi laporan terkait dengan dana desa itu bermacam-macam. Namun, jika dikelompokkan, ada 10 jenis penyimpangan pengelolaan dana desa yang dilaporkan. Kesepuluh penyimpangan yang dilaporkan tersebut adalah tidak adanya pembangunan di desa; pembangunan/pengadaan

barang/jasa tidak sesuai dengan spesifikasi/RAB; dugaan adanya mark up oleh aparat desa; tidak adanya transparansi; masyarakat tidak dilibatkan; penyelewengan dana desa untuk kepentingan pribadi; dan lemahnya pengawasan dana desa oleh inspektorat. Ada juga penyimpangan dalam bentuk kongkalikong pembelian material bahan bangunan, proyek fiktif, serta penggelapan honor aparat desa. Namun ke-459 laporan tersebut, belum tentu ada penyelewengan dana desa. Beberapa di antaranya hanya karena kesalahan administrasi atau proses yang tidak transparan.

KPK mengkaji dalam pengelolaan dana desa mempunyai kelemahan empat aspek yakni regulasi, tata

${ }^{17} \mathrm{https}$ ///news.detik.com/berita/d3592527/kpk-ada-459-laporan-soaldana-desa Rabu 09 Agustus 2017, 14:48 WIB laksana, pengawasan dan sumber daya manusia yang mengelola dana desa. ${ }^{18}$

Sehingga perlu disadari bahwa pencegahan dan pemberantasan korupsi merupakan pekerjaan yang sangat besar, berat, kompleks dan rumit serta beresiko tinggi pada aparatur penegak hukum, terlebih pada warga masyarakat yang berperan serta melaporkan tindak pidana korupsi, mutlak perlu dilakukan berbagai strategi. Oleh karena itu permasalahan korupsi bukan hanya tanggungjawab penegak hukum akan tetapi peran serta seluruh elemen masyarakat harus terlibat.

Demikian hal pelaksanaan penggunaan dana desa yang ideal serta sesuai pengaturan perundang-undangan yang berlaku, di Desa Cau Blayu tidak juga terlepas dari permasalahan yang dihadapi. Berikut beberapa kendala dan hambatan yang ditemui pada kenyataannya di lapangan oleh Masyarakat serta Perangkat Desa Cau Blayu sehubungan pengelolaan dana desa serta pada khususnya sebagai upaya pencegahan korupsi penggunaan dana desa tersebut.

Pertama, Sumber Daya Manusia (SDM) yang tersedia masih rendah dari segi pengetahuan atau keterampilan dalam penggelolaan dana desa, sehingga perlu pendampingan dan pembinaan dari pemerintah, kendala yang sangat terasa adalah SDM bidang teknologi informasi masih perlu diberikan banyak pelatihan. Serta kesulitan memahami tentang aturan dalam penggunaan dana maupun

${ }^{18} \mathrm{https} / / /$ news.detik.com/berita/d3584184/kpk-soroti-4-kelemahan-dana-desayang-buka-peluang-korupsi, diakses tanggal 14 Oktober 2017. 
pelaporan penggunaan dana sehubungan kurang sosialisasi pemerintah serta pengaturan tentang dana desa yang cepat sekali mengalami perubahan, contohnya setiap tahun minimal harus dilakukan pencarian informasi baru serta pembelajaran terhadap peraturan yang berubah-ubah mengikuti kebijakan pemerintah pusat.

Kedua, dari segi praktik pencairan dana desa dari pemerintah daerah pada kenyataannya seringkali mengalami kemunduran, dengan waktu yang mendesak atau kurang cukup sehingga pelaksanaan pembangunan desa tergesa-gesa sebab dana desa yang lambat turunnya akan mengakibatkan tidak efektif penyerapannya.

Ketiga, di Desa Cau Blayu sendiri, Badan Permusyawaratan Desa (BPD) belum dilibatkan dalam pengawasan pengelolaan dana desa karena dirasakan belum terlatih dengan baik. Selama ini BPD tidak terlalu memahami perannya karena belum pernah dilibatkan tentang sosialisasi dana desa padahal perannya sangat penting dalam pengawasan.

Keempat, permasalahan yang dialami Perangkat Desa Cau Blayu adalah kesulitan membuat pertanggungjawaban penggunaan dana desa yang dirasakan cukup sulit atau ribet oleh perangkat desa. Kondisi tersebut menuntut dilakukan pelatihan secara intensif dan berkelanjutan dari pemerintah daerah.

Selama ini pelatihan telah dilakukan diantaranya oleh Dispektorat Kabupaten Tabanan, Bagian Keuangan Kabupaten Tabanan, Bapeda (kepada perangkat desa), oleh Kepala Desa, Perbekel dan perangkatnya (kepada Kelian Subak), BPMD (kepada kepala dusun), sekalipun masih belum banyak dari segi kuantitas pelaksanaannya, permasalahan juga datang dari antusias masyarakat untuk terlibat dalam pelatihanpelatihan tersebut masih minim. Hal tersebut menunjukkan perlunya juga membangun kesadaran masyarakat, sebab pengelolaan dana desa yang baik dan efektif akan memberikan manfaat terhadap masyarkat juga dari sisi fasilitas umum maupun peningkatan kesejahteraan mereka.

Demikian halnya pengawasan, pernah dilakukan pengawasan oleh Dispektorat Kabupaten, BPK, Pengawas Kecamatan, Masyarakat dan Audit internal pemerintah, Inspektorat sehingga dari segi penyelewengan sampai dengan dilaksanakan studi di Desa Cau Blayu tidak pernah terjadi karena belum ada temuan ataupun pemeriksaan lebih mendalam terhadap dugaan-dugaan penyelewenangan ke arah korupsi.

Selain kendala diatas terdapat juga persoalan teknis belum dapat terpecahkan di Desa Cau Blayu sebagai contoh tidak sesuainya ongkos tukang kenyataan di lapangan dengan penetapan ongkos tukang dalam peraturan pelaksanaan penggunaan dana desa, kondisi di Bali umumnya upah tukang rata-rata lebih tinggi dibandingkan di daerah Jawa, sehingga mengakibatkan pengakal-akalan seperti memperbanyak jumlah hari kerja tukang dari jumlah sebenarnya hanya untuk menutupi selisih harga upah tukang tersebut.

Meskipun tergolong kecilkecilan dan dengan maksud dan tujuan yang baik yaitu terserapnya dana desa untuk 
pembangunan desa serta tidak ada upaya menguntungkan diri sendiri atau pihak lainnya, namun cara pengakalan tersebut merupakan perbuatan melawan hukum. Melihat kondisi tersebut tidak dapat hanya menuangkan kesalahan pada perangkat pelaksana di desa namun pemerintah juga harus berbenah diri dengan penyesuaian ketentuan yang dibuat dengan kondisi sebenarnya dalam masyarakat.

Kondisi di Bali sejauh ini masih sangat sedikit ada kasus indikasi tindak pidana korupsi menyangkut dana desa. Bahkan dengan besarnya gelontoran dana desa justru mengakibatkan beberapa kepala desa ragu menggunakan karena takut terjerat hukum ${ }^{19}$. Sekalipun demikian upaya pencegahan penyelewengan baik itu oleh pemerintah, penegak hukum maupun masyarakat dan perangkat desa harus terus dikembangkan untuk selalu mengawal penggunaan dana desa dengan benar.

Jawaban yang diberikan masyarakat Desa Cau Blayu ketika dihadapkan pertanyaan, bagaimana terkait peran serta masyarakat dalam pencegahan korupsi dana desa dalam hal ada dugaan penyelewenangan penggunaannya, warga bersedia melakukan pengawasan dan pelaporan namun mereka menghawatirkan keselamatan diri maupun keluarga sehubungan hal tersebut.

Berdasarkan Pasal 68 UU Desa mengatur hak dan kewajiban masyarakat desa untuk bisa mengakses dan dilibatkan dalam pembangunan desa. Penting karena masyarakat yang

\footnotetext{
${ }^{19} \mathrm{https} / / /$ balitribune.co.id/content/ adakades- ragu- gunakan-dana- desa, diakses 16 Oktober 2017.
}

mengetahui kebutuhan di wilayah desanya. Selain pelibatan peran masyarakat dalam melakukan pengawasaan dana desa, keberadaan Badan Perwakilan Daerah (BPD) perlu dimaksimalkan dalam menyerap aspirasi dan mengajak masyarakat terlibat aktif dalam pembangunan desa, mulai dari pemetaan kebutuhan, perencanaan, pengelolaan hingga pertanggungjawaban.

Partisipasi masyarakat (publik) dicantumkan pula dalam Pasal 1 angka 3 Peraturan Presiden Nomor 55 Tahun 2012 tentang Strategi Nasional Pencegahan dan Pemberantasan Korupsi Jangka Panjang Tahun 2012-2025 dan Jangka Menengah Tahun 2012-2014, dirumuskan:

Peran serta masyarakat adalah peran aktif perorangan, Organisasi Masyarakat, atau Lembaga Swadaya Masyarakat dalam pencegahan dan pemberantasan tindak pidana korupsi.

Salah satu upaya yang dapat dilakukan untuk tetap menjaga dan meningkatkan partisipasi publik dalam upaya menumbuhkan budaya anti korupsi adalah dengan memberikan apresiasi atau penghargaan. Pemberian penghargaan atas peran serta masyarakat dalam upaya menumbuhkan budaya anti korupsi bersifat terbuka dan dikampanyekan agar mendorong masyakarat lainnya untuk ikut berkontribusi.

Sehubungan penghargaan atas partisipasi publik dalam upaya pemberantasan korupsi, berdasarkan Pasal 7 - Pasal 11 PP Nomor 71 Tahun 2000:

\section{Pasal 7}

(1) Setiap orang, Organisasi
Masyarakat, rembaga
Swadaya Masyarakat yang


telah berjasa dalam usaha membantu upaya pencegahan atau pemberantasan tindak pidana korupsi berhak mendapat penghargaan.

(2) Penghargaan sebagaimana dimaksud dalam ayat (1) dapat berupa piagam atau premi.

\section{Pasal 8}

Ketentuan mengenai tata cara pemberian penghargaan serta bentuk dan jenis piagam sebagaimana dimaksud dalam Pasal 7 ayat (2) ditetapkan dengan Keputusan Menteri Hukum dan Perundangundangan.

\section{Pasal 9}

Besar premi sebagaimana dimaksud dalam Pasal 7 ayat (2) ditetapkan paling banyak sebesar 2 (dua permil) dari nilai kerugian keuangan negara yang dikembalikan.
Pasal 10
(1) Piagam yang diberikan kepada pelapor setelah perkara dilimpahkan ke Pengadilan Negeri.
(2) Penyerahan piagam sebagaimana dimaksud dalam ayat (1) dilakukan oleh Penegak Hukum atau Komisi.

\section{Pasal 11 \\ (1) Premi diberikan kepada Pelapor setelah putusan pengadilan yang memidana terdakwa memperoleh kekuatan hukum tetap. \\ (2) Penyerahan premi sebagaimana dimaksud dalam ayat (1) dilakukan oleh Jaksa Agung atau pejabat yang ditunjuk. \\ Sudah menjadi rahasia umum bahwa tidak mudah dan ada juga resiko bagi pelapor suatu dugaan tindak pidana korupsi, apalagi}

jika pihak yang dilaporkan orang atau sekelompok orang yang memiliki kekuasaan. Kerahasiaan identitas pelapor merupakan hal utama dalam pelaksanaan partisipasi publik ini. Oleh karena itu, mekanisme pemberian penghargaan perlu mempertimbangkan kerahasiaan identitas pelapor. Hal ini sebagaimana kewajiban penegak hukum untuk merahasiakan identitas pelapor yang diatur dalam Pasal 6 PP 71 Tahun 2000 sebagai berikut:

(1) Penegak hukum atau Komisi wajib merahasiakan kemungkinan dapat diketahuinya identitas pelapor atau isi informasi, saran, atau pendapat yang disampaikan.

(2) Apabila diperlukan, atas permintaan pelapor, penegak hukum atau Komisi dapat memberikan pengamanan fisik terhadap pelapor maupun keluarganya.

\section{KESIMPULAN}

Berdasarkan penjelasan tersebut diatas dari hasil penelitian dan studi yang telah dilakukan sehingga dapat diambil suatu kesimpulan sebagai berikut:

4.1.1. Peran serta masyarakat dalam upaya pencegahan korupsi dana desa telah tercermin dalam rumusan perundang-undangan yang ada antara lain: Kitab UndangUndang Hukum Pidana, UU Pemberantasan Tindak Pidana Korupsi, UU Komisi Pemberantasan Tindak Pidana Korupsi, UU Penyelenggaraan Negara yang Bersih dan Bebas dari KKN sampai dengan peraturan pelaksanaannya. Namun pemahaman warga Desa Cau Blayu masih sangat 
minim tentang tindak pidana korupsi, serta pentingnya peran warga dalam mencegah terjadinya tindak pidana korupsi khususnya sehubungan dengan pengelolaan dana desa. Beberapa kendala dan hambatan yang ditemui pada kenyataannya di lapangan oleh Masyarakat serta Perangkat Desa Cau Blayu sehubungan pengelolaan dana desa serta pada khususnya sebagai upaya pencegahan korupsi penggunaan dana desa antara lain: (1) SDM yang tersedia masih rendah dari segi pengetahuan atau keterampilan dalam penggelolaan dana desa sehingga perlu pendampingan dan pembinaan dari pemerintah; (2) segi praktik pencairan dana desa dari pemerintah daerah pada kenyataannya seringkali mengalami kemunduran, dengan waktu yang mendesak atau kurang cukup sehingga pelaksanaan pembangunan desa tergesa-gesa sebab dana desa yang lambat turunnya akan mengakibatkan tidak efektif penyerapannya; (3) Badan Permusyawaratan Desa belum dilibatkan dalam pengawasan pengelolaan dana desa karena dirasakan belum terlatih dengan baik (4) kesulitan membuat pertanggungjawaban penggunaan dana desa, sehingga menuntut dilakukan pelatihan secara intensif dan berkelanjutan dari pemerintah daerah. Selain itu ada kekhawatiran warga dalam melakukan pencegahan korupsi dana desa sehubungan dengan perlindungan diri atau keluarga. Beberapa perundang-undangan telah memberikan jawaban atas pertanyaan tersebut diantaranya: partisipasi masyarakat (publik) dicantumkan dalam Peraturan Presiden Nomor 55 Tahun 2012 tentang Strategi Nasional Pencegahan dan Pemberantasan Korupsi Jangka Panjang Tahun 2012-2025 dan Jangka Menengah Tahun 2012-2014 serta terhadap penghargaan atas partisipasi publik dalam upaya pemberantasan korupsi, berdasarkan PP Nomor 71 Tahun 2000 tentang Tata Cara Pelaksanaan Peran Serta Masyarakat dan Pemberian Penghargaan dalam Pencegahan dan Pemberantasan Tindak Pidana Korupsi.

\section{DAFTAR PUSTAKA}

\section{Buku}

Hartanti, Evi, 2012, Tindak Pidana Korupsi Edisi Kedua,Sinar Grafika, Jakarta.

Klitgaard, Robert, dkk., 2002, Penuntun Pemberantasan Korupsi dalam Pemerintahan Daerah, Yayasan Obor Indonesia \& Partnership for Governance Reform in Indonesia, Jakarta.

M Abdul Kholik, AF., Eksistensi KPK dalam Peradilan Korupsi di Indonesia, Artikel dalam Jurnal Hukum FH UII, No.26, Vol.11.

Makawimbang, Hernold Ferry, 2015, Memahami dan Menghindari Perbuatan Merugikan Keuangan Negara, dalam TIndak Pidana Korupsi dan Pencucian Uang, Thafa Media, Yogyakarta.

Nurdjana, IGM, 2010, Sistem Hukum Pidana dan Bahaya Laten Korupsi, Perpektif Tegaknya Keadilan Melawan Mafia Hukum, Pustaka Pelajar, Yogyakarta.

Soemodihardjo, R.Dyatmiko, 2008, Mencegah dan Memberantas Korupsi, Mencermati Dinamikanya di Indonesia, Prestasi Pustaka, Jakarta. 
Suryadi, Ni Putu Leona Laksmi, 2016, Penanggulangan Tindak Pidana Korupsi dalam Pengelolaan Keuangan Dana Desa di Bali, Skripsi, Fakultas Hukum, Unud.

Bagus

Praetyo, 2016

https://m.tempo.co/read/news/2016/01/27/063739957/ini-daftarperingkat-korupsi-dunia-indonesia-urutan-berapa, diakses 10 Maret 2016.

\section{Website}

http://marga.tabanankab.go.id/profil-desa/desa-cau-belayu/diakses

Maret 2016.

https://news.detik.com/news/berita/d-3487085/mendes - tahun - depan alokasi - dana-naik-tiap -desa/jumat.

https://nasional.tempo.co/read/899049/ini - upaya-kpk -cegah-terjadinya -korupsi- dana-desa.

http://www.hukumonline.com / berita / baca / lt598f2a9e656ee/ cegah korupsi --masyarakat-perlu-dilibatkan-awasi-dana-desa.

https://news.detik.com/berita/d-3592527/kpk-ada-459-laporan-soal dana- desa.

https://news.detik.com/berita/d-3584184/kpk-soroti-4 kelemahan - dana - desa-yangbuka-peluang-korupsi. 